\title{
The Application of Antitrust Law to Telecommunications
}

The Supreine Court has allowed antitrust actions against several regulated industries, holding that the fact of regulation does not imply a blanket antitrust immunity. ${ }^{1}$ The Court has not, however, confronted the relationship between the antitrust laws and the present regulatory scheme for telephonic coinmunications. This Comment undertakes that task. ${ }^{2}$ The relationship between antitrust and regulation is one facet of a larger pohicy choice between a competitive and an administered imdustry structure. The initial choice in favor of government administration expressed in the Coinmunications Act of $1934^{3}$ was based on the economic wisdom, prevailing technology, and national needs of the 1930's. Nearly fifty years later these bases no longer seem coinpelhing. The "natural monopoly" justification for telecommunications regulation is under attack. ${ }^{4}$ Technological change in the last four decades has drastically altered the cost structure of the industry, and there is every reason to beheve it will continue to do so. ${ }^{5}$ Many argue that

1. Otter Tail Power Co. v. United States, 410 U.S. 366 (1973) (electric power transmission); Carnation Co. v. Pacific Westbound Conference, 383 U.S. 213 (1966) (shipping); United States v. Philadelphia Nat'l Bank, 374 U.S. 321 (1963) (banking); United States v. RCA, 358 U.S. 334 (1959) (broadcasting). Similarly, the mere presence of state regulation alone does not confer immunity. See City of Lafayette v. Louisiana Power \& Light Co., 435 U.S. 389 (1978); Cantor v. Detroit Edison Co., 428 U.S. 579 (1976).

2. This Comment will focus on telephone services, including the transmission of data via the phone lines. No attempt will be made to assess the antitrist implications of the FCC's broadcast regulating authority. Readers should be cautious about generalizing from these pages to noncommon-carrier situations such as broadcasting. As will be seen, the application of the antitrust laws is highly dependent upon the nature and intricacy of the specific regulatory scheme. The Communications Act of 1934 covers broadcast and common carriers in two distinct sections. Broadcast carriers are regulated pursuant to chapter 5, subchapter II of Title 47 of the UNITED STATES CODE, 47 U.S.C. \$§ 301-399 (1976 \& Supp. IlI 1979); telecommunications common carriers are regulated under chapter 5, subchapter III, 47 U.S.C. $\$ \$ 201-224$ (1976 \& Supp. III 1979). Judicial and FCC decisions dealing with the broadcast industry will be treated here with this caveat in mind.

3. 47 U.S.C. $\$ \S 151-609$ (1976 \& Supp. III 1979).

4. A natural monopoly exists where, because of high fixed costs and declining variable costs, the most efficient imdustry structure is one in which a single producer supplies the entire market. Waverman, The Regulation of Intercity Telecommunications, in Promoting CompetItion In Regulated Markets 201-39 (A. Phillips ed. 1975) (absence of plant, firm, and multiproduct economies of scale; presence of contracting economies).

5. Irwin, Vertical Integration and the Communications Industry: Alternatives for Public Policy, 53 CORNELl L. Rev. 446, 458 (1968) (development of microwave transmission); Robimson, Policy Perspectives for the 1980's, in COMMUNICATIONS FOR TOMORROW (G. Robimson ed. 1978); Trebing, Common Carrier Regulation-The Silent Crisis, 34 LAw \& CONTEMP. ProB. 299, 307-10 (1969). 
the original purpose of the Communications Act, universal service, has been met and that other goals such as the encouragement of innovation, should now be pursued. ${ }^{6}$

The regulation/antitrust relationship reduces to two underlying issues: (1) whether there should be coinpetition at all, and (2) if so, who should administer the rules of the competitive gaine. In the courts, the question whether there should be competition arises in the form of claims that the regulatory statute creates an imphed repeal of the antitrust laws vis-à-vis the regulated industry. The question of who shall referee the coinpetitive rules is resolved through decision of a set of procedural issues such as primary jurisdiction, the collateral estoppel effect on an antitrust court of prior agency determinations, and the proper weight to be given agency policies im the formulation of antitrust remedies.

Part I of this Comment will describe the structure of the telephone industry, identify the competitive issues, and outline the recent development by the Federal Communications Commission (FCC or Commission) of a procompetitive policy in the provision of intercity telephone services. It will also discuss the practical necessity for judicial application of the antitrust laws, given the inadequacy of the Communications Act to deter anticompetitive behavior. Part II analyzes the approacli the Supreine Court has used in deciding whether the law of antitrust apphes $\mathrm{n} 1$ a regulated industry, and concludes that the apphcation of the antitrust laws to telephonic common carriers is not precluded by current case law. Part III addresses the procedural question of whether a court should refer an issue of fact to the FCC once an antitrust cause of action is allowed against a regulated defendant. Finally, Part IV disposes of various objections to the apphication of antitrust remedies against regulated defendants.

I

The Telecommunications Industry

\section{A. Structure and the Growth of Competition}

\section{Industry Structure}

Intercity telephone service coinprises three basic technological coinponents: intercity transmission, local station service, and user

6. For the view that competitive structure is more conducive to innovation, see M. IRWIN, THE TELECOMMUNICATIONS INDUSTRY 159-60 (development of microwave transmission), 456-57 (innovation in equipment manufacture) (1971); Irwin, supra note 5, at 457 (innovative results of nonintegrated producers); Noll, The Economics \& Politics of Regulation, 57 VA. L. Rev. 1016, 1022-23 (1971); Shephard, The Competitive Margin in Comnumications, in TECHNOLOoICal Chanae in Regulated Industries 103, 109-12 (W. Capron ed. 1971). But see Posner, Natural Monopoly and Its Regulation, 21 StAN. L. REv. 548, 582 (1969). 
equipment. A single call can be diagrammed thus: ${ }^{7}$

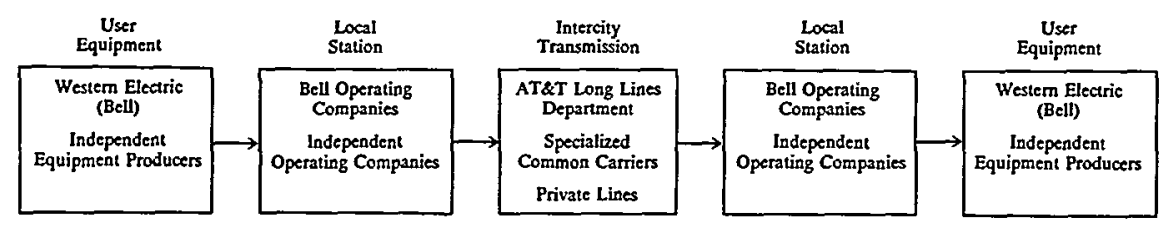

The structure of the Bell system reflects these technological components. Intercity transmission is provided by the Long Limes Department of AT\&T. Local service is provided through AT\&T by its twenty-three operating companies. ${ }^{8}$ Western Electric, ${ }^{9}$ a wholly-owned subsidiary of AT\&T, manufactures equipment to supply fifteen percent ${ }^{10}$ of the domestic equipment market. The research arm, Bell Laboratories, is jointly owned by AT\&T and Western Electric.

The Bell System ${ }^{11}$ doininates the domestic voice-grade telecommunications market. Smaller competitors exist in each of the three component areas, but their size and market shares are dwarfed by AT\&T. For example, there are over 1,488 local operating companies serving one-half of the land area of the United States. However, the twenty-three Bell operating companies collect nearly eighty-five percent of total operating company revenue. ${ }^{12}$

Both Bell and the imdependent operating companies are local monopolies, although there is occasional competition for newly developed fringe territory. ${ }^{13}$ In the past two decades, competition has developed in equipment and intercity transmission. The structure of the industry has changed drastically simce the Communications Act of 1934 became law. ${ }^{14}$

7. This process is described in more detail in Robinson, supra note 5, at 93 .

8. For a general description of the Bell Systein, see M. IRwIN, supra note 6, at 25-30; B. Owen \& R. Braeutigam, The Regulation Game 201-04 (1978).

9. A recent FCC decision requires the Western Electric Division that produces equipment used on the customer's premises to function as a separate subsidiary of AT\&T. Second Computer Inquiry, 77 F.C.C.2d 384 (1980). To meet "Inaximum separation requirements," there must be separate officers and operating personnel as well as the separation of marketing, installation, and maintenance functions. Id. at 477 . Research and development may be shared, but only on a fully cost-compensatory basis. Id. at 480 .

10. Trebing \& Melody, Entry Conditions in Telecommunications, in M. KLASS \& W. SHEPHARD, REGULATION AND ENTRY 95 (1976).

11. "Bell," "the Bell systen," and "AT\&T" will be used interchangeably to refer to the entire integrated entity unless otherwise indicated.

12. B. OWEN \& R. BRAEutigam, supra note 8, at 201-04.

13. See Woodlands Telecoin. Corp. v. AT\&T, 447 F. Supp. 1261 (S.D. Tex. 1978), remanded for new instructions, 615 F.2d 1372 (5th Cir. 1980).

14. M. IRWIN, supra note 6, at 78-93. 


\section{The Development of Competition}

The major competitive issues have been equipment interconnection, competition in intercity services, both private line and long distance phone service for the general public.

\section{a. Equipment}

The growth of the computer industry in the 1950's and 1960's produced new types of equipment, such as data modems to connect terminals in remote locations via telecoinmunications. ${ }^{15}$ Despite the growing demand of consumers to own and connect their new equipinent to the telecoinmunications system, the Commission had long allowed common carriers to forbid the use of customer-supplied equipnient. The rationale was to protect the integrity of the carrier's hardware, but the rules forbade connection of all customer-supplied equipment, whether or not it was actually incompatible. ${ }^{16}$ In the 1968 Carterfone $^{17}$ decision, the Commission decided that this prohibition was unreasonable, thereby opening the equipment market to competition. $^{18}$

Recently, the FCC has taken steps to encourage competition in the production and sale of customer equipment. In its Second Computer Inquiry ${ }^{19}$ the Commission imposed separate subsidiary requirements on the two largest integrated producers of customer-premises equipinent: AT\&T and General Telephone. The Commission expressed a preference for a fully competitive market in equipment, but felt that the inarket power of other independent phone companies was not great enough to require separate subsidiaries as a safeguard against crosssubsidization or other abuse. ${ }^{20}$

15. A. Oetringer, P. Berman \& W. Read, High and Low Politics: Information ReSOURCES FOR THE $80^{\prime}$ 's, at 3 (1977). The computer industry also provided the talent to produce the new telecommunications equipment. See Trebing \& Melody, supra note 10, at 11; Mitel Finds Niche in Telecommunications and Establishes Firm Industry Foothold, Wall St. J., Jan. 18, 1980, at 8 , col. 1 .

16. See Southwestern Bell Tel. Co. v. Dialite Dial Co., 102 F. Supp. 872 (W.D. Okla. 1951), appeal dismissed, 197 F.2d 523 (10th Cir. 1952) (prohibition against attaching dial advertising disc upheld).

17. Carterfone Device, 13 F.C.C.2d 420 (1968).

18. See generally B. OWEN \& R. BRAEUTIGAM, supra note 8, at 195-97.

19. 77 F.C.C.2d 384 (1980).

20. Id. at 468 . Cross-subsidization is the practice of subsidizing lower rates on services that face competition by maintaining high rates on services enjoying a monopoly. 


\section{b. Intercity Transmission}

The three major types of intercity service offermgs are message toll telephone service (MTS), wide area telephone service (WATS), and private line service (PLS). MTS is long distance service billed on a percall basis. WATS provides unlimited calling throughout a designated area for a flat fee. ${ }^{21}$ Private line services are point-to-point dedicated channel services used by those with high volume or a need for an open link between two points. ${ }^{22}$ The three services can be provided over the same transmission facilities. ${ }^{23}$ Competition in the intercity transmission market began with PLS and is spreading to MTS.

Besides producing new kinds of equipinent, the computer revolution altered supply and demand conditions im the provision of intercity transmission. ${ }^{24}$ Computer and other new uses created a need for telecommunications services with different price, rehability, and speed parameters than those of the traditional monopoly voice service. ${ }^{25}$ The absolute size of the new demand was small relative to the overall intercity transmission market. ${ }^{26}$ Consequently, although the Bell system was capable of offering the desired services, it did not do so before potential entrants sought to provide them. The FCC favored entry into PLS, determining im its Specialized Common Carrier ${ }^{27}$ decision that "a general pohicy in favor of the entry of new carriers in the specialized communications field would serve the pubhic interest, convenience, and necessity."28 The Commission rejected AT\&T's argument that new entrants should be authorized ${ }^{29}$ only where the Bell system had no capacity to provide the service. ${ }^{30}$ The Commission ignored the objection that

21. FCC OK's Resale, Sharing of AT\&T Long-Distance Lines, Los Angeles Times, Oct. 22, $1980, \S$ IV, at 1 , col. 3.

22. A. OetTinger, P. Berman \& W. Read, supra note 15 , at 50.

23. Id. at 50,55 .

24. Id. at 95 (supply), 147-53 (convergence of technologies and functions of commumications and data processing); B. OWEN \& R. BRAEUtigam, supra note 8, at 207-08 (demand).

25. See Comment, The Proposed Deregulation of Domestic Common Carrier Telecommunications, 69 CALIF. L. REv. 455, 474 nn. 122-26 (1981).

26. Trebing \& Melody, supra note 10 , at 96.

27. Specialized Coinınon Carrier Services, 29 F.C.C.2d 870 (1971).

28. Id. at 920 .

29. Section 214 of the Communications Act requires a certificate of public convenience and necessity for the acquisition or construction of common carrier facilities. At the time of the Specialized Common Carrier decision, the FCC took the view that $\$ 214$ gave it the power to authorize or deny new entry. See text accompanying notes 32-33 infra (discussion of Execunet) for subsequent interpretations of $\S 214$ authority.

30. Specialized Common Carrier Services, 29 F.C.C.2d 870, 902 (1971). In the recent Second Computer Inquiry, the Commission required AT\&T to use a separate subsidiary to provide customer equipment and "enhanced" transmission services, whicl can be considered a subset of the Specialized Common Carrier category. 77 F.C.C.2d 384 (1980). The Commission lias also issued a proposal that rate review and other regulatory requireinents be eased for nondominant specialized common carriers. Competitive Carrier Rulemaking, 77 F.C.C.2d 308 (1979). 
high profit routes, and thus the ability to subsidize other routes, would be lost, because private line interstate service accounted for less than four percent of overall Bell systein revenues. ${ }^{31}$

After Specialized Common Carrier, Bell faced competition for private line users. Today, it also faces competition for some MTS users. As a result of Microwave Telecommunications Corp. v. FCC (Execunet),$^{32}$ which limited the FCC's power to restrict the use of existing facilities, the specialized carriers are now free to offer services very much like MTS, the traditionally monopolized long distance service.

In Execunet, a specialized common carrier sought judicial review of an FCC denial of its filing for provision of a new service, "Execunet," that would bear characteristics similar to message toll service. The FCC had denied the application, citing its original section 214 authorization of the applicant MCI, and stating that it had authorized the entrant to provide specialized but not message toll service. The Court of Appeals for the District of Columbia Circuit reversed. It found that the purpose of section 214 was to allow the FCC to prevent facihty duplication, not to control entry in order to promote inonopoly organization. Citing another part of section $214,{ }^{33}$ the court said that the FCC could restrict use of existing facilities only on an affirmative finding that the restriction is necessary in the public interest. ${ }^{34}$

\section{B. Practical Reasons for Applying the Antitrust Laws}

Specialized Common Carrier and Execunet represent a policy choice in favor of competition in intercity transmission. But the current Conımunications Act has not effectively enforced that choice by deterring cross-subsidization and other anticompetitive behavior. Application of the antitrust laws would enhance competition in at least two ways: providing a more convenient or sympathetic forum, and providing remedies not available under the Communications Act.

The inultiplicity of private antitrust suits suggests the inadequacy of the current regulatory systen to deter anticompetitive behavior. ${ }^{35}$ In part, the private suits inay have resulted from a perception that the FCC has been "captured" by AT\&T. ${ }^{36}$ Althougl commentators have

31. Specialized Common Carrier Services, 29 F.C.C.2d at 911.

32. 561 F.2d 365 (1977).

33. 47 U.S.C. $\$ 214$ (c) (1976).

34. $561 \mathrm{~F} .2 \mathrm{~d}$ at 377 .

35. See note 59 infra.

36. "Capture" is shorthand for the concern that the regulators take on the view of the regulated. See Jaffe, The Effective Limits of the Administrative Process: A Reevaluation, 67 Harv. L. REv. 1105, 1107-12 (1954). A complainant fearing FCC capture might hope by an antitrust action to substitute the court as decisionmaker. This result will be achieved in some but not all instances where there is in fact an antitrust cause of action. See text accompanying notes 57, 106-41 infra 
attached the pejorative term "forum shopping" to the attempt to choose the most favorable forum, ${ }^{37}$ there are valid considerations that could make a court, rather than the FCC, the more hospitable forum for enforcing competitive norms.

First, until recently the courts liave shown a stronger commitment to competition than has the FCC. ${ }^{38}$ Second, an antitrust cause of action enables local and regional carriers or small equipment manufacturers to sue in their local areas. ${ }^{39}$ For example, a dispute may arise from AT\&T's refusal to interconnect its long lines network with an mdependent local operating company that had previously made its facilities available for connection with mdependent long lines carriers. This is a classic boycott ${ }^{40}$ to which antitrust standards should apply, and which also offends the procompetitive policies of Execunet. Thus, by inaking access to a judicial forum more convenient for plaintiffs, the availability of a private antitrust cause of action would also support the recent procompetitive actions of the FCC. Most importantly, an antitrust court can provide an adequate remedy for anticonıetitive behavior where the FCC is unable to do so. ${ }^{41}$

The 1934 Communications Act did not envision an evolving tecl1nology that would inake conipetition in the telephone equipment and intercity transimssion markets a practical reality. ${ }^{42}$ Thus, it is not surprising that the Act fails to provide remedies effective agamst competitive abuses ${ }^{43}$-such as cross-subsidization (enabling predatory rates on

(discussing primary jurisdiction). But recent FCC actions belie the claim that the Commission lias been captured by the industry. See note 30 supra.

37. See Comment, New Twists and Old Wrinkles: Primary Jurisdiction and Regulatory Accommodations with the Antitrust Laws, 15 B.C. Indus. \& CoM. L. REv. 80, 86-89 (1973).

38. See notes 19-20 and accompanying text supra.

The recent actions of the FCC to create structural changes conducive to fostering competition in equipment and data processing, and its exploratory steps toward deregulation of nondominant special carriers show a strong procompetitive attitude on the part of a majority of the Commissioners. See Second Computer Inquiry, 77 F.C.C.2d 384 (1980); Coinpetitive Carrier Ruleınaking, 77 F.C.C.2d 308 (1980).

39. Of course, facts establishing the jurisdiction of the district court over the defendant must be alleged.

40. A classic boycott is an attempt by an actor or group to lrann a competitor at its level by inducing action at another level. See L. Sullivan, ANTrTRust 230 (1977).

41. See note 43 infra.

42. Trebing, supra note 5, at 306-07, 316-17. See also Jaffe, supra note 36, at 1119 (pointing out that when the regulatory acts were passed in the 1930's many thought they were legislation for a mature or even senescent industrial system: "Administration was a branch of geriatrics.").

43. The structure of the FCC's review powers creates an incentive to engage in anticompetitive practices. The Act requires reasonable rates. 47 U.S.C. $§ 201$ (1976). The Commission may imvestigate rates and order refunds of customer overpayments, 47 U.S.C. $\$ \S 205-209$ (1976), but it appears to have no power to award damages for harm suffered by competitors during the period that unreasonable rates were in effect. 47 U.S.C. $\$ \S 206-209$; see MCI Telecom. Corp. v. AT\&T, 462 F. Supp. 1072, 1087-88 (N.D. Ill. 1978). The Commission may snspend rates for up to five months, 47 U.S.C. $\S 204$ (1976), but this period has proved inadequate. See text accompanymg 
services facing coinpetition) or the use of monopoly power at one level to gain or hold control at another level (for example, where a monopoly local operating company refuses to connect imtercity competitors of its parent).

The inadequacy of the current regulatory scheme to deter competitive abuses is exemphified by the failure of DATRAN, a speciahized carrier that offered a new service: digital transmission over a switched network. AT\&T responded to the competition by proposing to establish digital transmission services over existing microwave routes to selected cities, under the rubric Dataplione Digital Service (DDS). In March of 1974, AT\&T submitted tariffs for DDS that were lower than tariffs for other existing services over the same routes. DATRAN complained to the FCC that the DDS rates were predatory. The Commission commenced an investigation in December 1974, but allowed the rates to go into effect in the first five cities of the proposed networkthe same cities in which DATRAN was operating. In June 1976, the FCC found that the DDS rates were unreasonable because the AT\&T costing documentation had treated both the existing analog routes and the research and development costs of DDS as free economic goods. Yet, the predatory rates had been in effect nineteen months, and the FCC decision was too late to mitigate the harm. DATRAN filed for bankruptcy in August 1976 and ceased all operations in September $1976 .{ }^{44}$

As the DATRAN case shows, the current structure of the Communications Act provides a positive incentive to engage im anticompetitive conduct. A carrier inay "mitiate an illegal, noncompensatory rate and by the time that rate is finally held to be illegal the . . . competitor [is] irreparably crippled or destroyed." 45 The FCC admits that it is without authority to remedy such conduct under the current Act. ${ }^{46}$

Proposed legislation to replace or amend the 1934 Act would cure this problein by requiring the creation of separate subsidiaries and arm's length dealing betwcen equipment manufacturers, local station services, coinpetitive services, and monopoly services. ${ }^{47}$ Short of divestiture or separation of management, accounting standards may help

notes 44-46 infra. The Commission may not require that rates receive affirmative approval before becoming effective. AT\&T v. FCC, 487 F.2d 865 (2d Cir. 1973). The reason for limiting the FCC's suspension power is to allow competitors to make rapid adjustments to market conditions. However, combimed with the absence of FCC authority to award damages to a competitor, the suspension limitation creates an imcentive for predatory pricing.

44. See generally B. OWEN \& R. BRAEUTIGAM, supra note 8, at 223-28.

45. Id. at 266 (quoting $A T \& T, 62$ F.C.C.2d 815, 847 n.64 (1976)).

46. Id.

47. Some economists favor an approach which separates the management of services facing competition from monopoly services. See Robinson, supra note 5, at 482 . For discussion of legislative approaches, see Comment, supra note 25 , at 476-96. 
to prevent anticompetitive subsidization..$^{48}$ Even without such legislation, however, judicial application of the antitrust laws would tend to deter anticompetitive behavior by threatening exposure to treble damages. ${ }^{49}$ By being receptive to antitrust actions, the courts would also support the Commission's recent position that it has the power under the current Act to order separate subsidiary organizations for corporate divisions engaged im the production and sale of customer-premises equipinent and of enhanced data transmission services. ${ }^{50}$

II

Application of Antitrust Standards to Regulated INDUSTRIES: The IMPLIED IMMUNITy PARADIGM

Application of antitrust law to the telecommumications industry may be a practical necessity to foster competition. This Comment will demonstrate that such an application is possible within the existing legal framework.

Even though the Supreine Court has yet to decide whether the antitrust laws apply to the telephone industry, the Court's treatment of the question with respect to other regulated imdustries should be imstructive. The Court has approached the problein as one of harmonizing two potentially inconsistent federal statutes. ${ }^{51}$ Thus, the Court has framed the question as whether Congress intended to repeal the antitrust laws with respect to the particular industry ${ }^{52}$ when it enacted the regulatory scheme. Since the Court has proceeded from the maxim that implied repeals are not favored, ${ }^{53}$ the application of the antitrust laws to federally regulated industries would appear to be presuined.

This presumption against immumity was set up by the Warren Court and has since been cited with approval by the Burger Court. Cantor v. Detroit Edison ${ }^{54}$ and City of Lafayette v. Louisiana Power \&

48. The great weakness of an attempt to halt or deter predatory pricing activity using accounting standards is the dependence of the FCC on carrier-supplied data. Given the relative sizes of staff and of resources of the regulated and the regulator, this dependence inay be unavoidable.

49. The actual deterrence value of application of antitrust liability, mcluding treble danages, is, of course, highly speculative. The availability of per se standards of liability and tactics causing delay and increasing costs, sucl as extensive discovery and primary jurisdiction requests, will bear on the deterrence value. However, the immediate problem with the existing regulatory sclieine-the mcentive to engage in anticompetitive conduct that springs from the structure of the agency's powers-will be removed.

50. Second Coinputer Inquiry, 7I F.C.C.2d 384 (1980) (AT\&T and GTE ordcred to observe "maximuin scparation requireinents" in order to reinove the opportunity to cross-subsidize).

51. See United States v. National Ass'n of Sec. Dealers, Inc., 422 U.S. 694, 719-20 (1975).

52. See Otter Tail Power Co. v. United States, 410 U.S. 366, 372 (1973); United States v. Philadelphia Nat'l Bank, 374 U.S. 321 (1963).

53. United States v. Philadelphia Nat'1 Bank, 374 U.S. 321 (1963).

54. 428 U.S. 579 (1976). 
Light Co. ${ }^{55}$-raised the issue of the scope of the state action exemption from the antitrust laws. The Court stated that exemptions, like immunities, are not favored, and are to be narrowly construed..$^{56}$ The issue of implied immunity 57 for the telecommunications industry under the Communications Act has arisen in numerous district courts and has been the subject of several appellate decisions. In the Department of Justice suit agamst AT\&T, the district court decided there was no immunity. ${ }^{58}$ A similar result has been reached in many of the private antitrust cases, except where there has been prior regulatory agency approval of the specific challenged behavior. ${ }^{59}$ Under the scheme apparent in Supreme Court cases, immunity will be found either where there

55. 435 U.S. 389 (1978).

56. Cantor was a 6-3 decision, producing three opinions. Chief Justice Burger concurred only in the result and part of the plurality opinion, while Justice Blackmun concurred only in the judgment. The favorable citation of Otter Tail, a inajor no-immunity case, occurred in a portion of the plurality opinion joined by five Justices. 428 U.S. at 596, n.34. Lafayette produccd a similarly divided court. Justice Brennan applied "the presuınption against repeal by inuplication" to the issue of inplied exemptions in Part I of his opinion, a part that was joined by five Justices. 435 U.S. at 398-99 (1978). Burger's concurrence appears to go even farther: "There is no logical inconsistency between requiring such a firm [inunicipal utility] to meet regulatory criteria insofar as it is exercising its natural monopoly powers and also to comply with antitrust standards to the extent that it engages in business activity." Id. at 425 (Burger, C.J., concurring).

57. "Implied immunity" should be distinguished from "primary jurisdiction." An antitrust complaint against a telephone company is commonly met with two distinct defenses-both, confusingly, likely to pass under the label of "primary jurisdiction." The first defense clainis that the regulatory statute has inpliedly repealed the antitrust laws; therefore, there is no antitrust cause of action at all. The early cases refer to this as exclusive primary jurisdiction. In a second defense, defendants often assert that even if there is no inphied immunity from antitrust law, the antitrust suit raises factual or policy issues that should be decided in the first instance by the FCC. This is nonexclusive, or "prior resort" primary jurisdiction, and it may entail a stay of the antitrust proceedings. It is not a denial of the cause of action, but only an effort by the court to defer to regulatory policy or take advantage of agency expertise. The conditions that should govern primary jurisdiction referral are discussed at text accompanying notes 106-41 infra.

58. United States v. AT\&T, 427 F. Supp. 57 (D.D.C. 1976) (Waddy, J.), cert. denied, 429 U.S. 1071 (1977). Simce Judge Waddy died during the proceedings, the case was subsequently assigned to Judge Greene, who independently analyzed the immunity clain to reach the same results. United States v. AT\&T, 461 F. Supp. 1314 (D.D.C. 1978).

59. Immunity has been granted in the private suits where it was found there had been prior affirmative FCC or state approval. See Jeffrey v. Southwestern Bell Tel. Co., 518 F.2d 1129 (5th Cir. 1975) (immunity where rate was approved by municipality after thorough hearings); Business Aides, Inc. v. Chesapeake \& Potomac Tel. Co., 480 F.2d 754 (4th Cir. 1973) (immunity where alleged violation was action based on a tariff expressly approved by state public utilities commission); Lamb Enterprises v. Toledo Blade Co., 461 F.2d 506 (5th Cir.), cert. denied, 409 U.S. 1001 (1972) (immunity on similar facts). But see Phonetele, Inc. v. AT\&T, 435 F. Supp. 207 (C.D. Cal. 1977) (immunity in absence of express prior FCC approval).

In other cases there has been no immunity. See Essential Com. Sys., Inc. v. AT\&T, 610 F.2d 1114 (3d Cir. 1979) (reversal of district court decision granting immunity for refusal to allow equipinent connection based on interim tariff); Industrial Com. Sys., Inc. v. Pacific Tel. \& Tel. Co., 505 F.2d 152 (9th Cir. 1974) (no immunity, primary jurisdiction in state PUC); MCI Telecom. Corp. v. AT\&T, 462 F. Supp. 1072 (N.D. Ill.), aff'd sub nom. AT\&T v. Grady, 594 F.2d 594 (7th Cir. 1978), cert. denied sub nom. AT\&T v. MCI Telecoin. Corp., 440 U.S. 971 (1979) (no immunity, no exclusive jurisdiction in FCC); Citizens Util. Co. v. AT\&T, [1978-1] TrADE CAS. (CCH) $\pi$ 
was an actual intent to repeal antitrust law as to the regulated industry, or where inference of that intent is thought appropriate. ${ }^{60}$ Even though implied immunity is not favored, inference of such intent inay be inade from (1) the existence of conflicting standards (necessity), (2) the extensive structure of the powers given to the regulatory agency (pervasiveness), or (3) the self-regulatory character of the regulatory scheine (selfregulatory exception).

\section{A. Irreconcilable Conflict}

The necessity rationale for implying immunity has been described as the "necessity to avoid irreconcilable conflict" or the "plaim repugnancy" of the regulatory act with the antitrust laws. ${ }^{61}$ If standards apphed by the antitrust court condemn actions approved by the agency, there is irreconcilable conflict. Thus, prior affirmative FCC approval of a challenged practice should provide immunity or at least extinguish liability for treble damages. ${ }^{62}$ It would be unfair to defendants to hold them hable for conduct when they justifiably relied upon the agency endorseinent of the legality of that conduct. An analogous decision of the Supreme Court supports this conclusion. In Gordon v. New York Stock Exchange, Inc., ${ }^{63}$ the Court equated conduct under an SEC rule with conduct pursuant to a formal order, declaring that there could be no antitrust liability for mandated acts. ${ }^{64}$ But the reliance and fairness interests are compelling only where there has been actual prior approval of the tariff or practice. The tariff, which beconies effective merely by acquiescence of the agency, should not create immunity ${ }^{65}$ Moreover, mere congressional intent to place in the FCC decisionmaking authority over rates and practices is insufficient to support implied

61,959 (N.D. Cal. 1977) (no immunity, primary jurisdiction in FCC over rates filed but not yet affirmatively approved or disapproved).

60. See Mt. Hood Stages, Inc. v. Greyhound Corp., 555 F.2d 687, 691 (9th Cir. 1977) (citing cases), vacated and remanded, 437 U.S. 322 (1978) (on unrelated statute of limitations issue).

61. United States v. National Ass'n of Sec. Dealers, Inc., 422 U.S. 694, 719-20 (1975) (citing United States v. Philadelphia Nat'l Bank, 374 U.S. 321, 350-51 (1963)); Otter Tail Power Co. v. Unitcd States, 410 U.S. 366, 372 (1973); United States v. Borden Co., 308 U.S. 188, 197-206 (1939).

62. Jeffrey v. Southwestern Bell Tel. Co., 518 F.2d 1129 (5th Cir. 1975); Business Aides, Inc. v. Chesapeake \& Potomac Tel. Co., 480 F.2d 754 (4th Cir. 1973); Lamb Enterprises v. Toledo Blade Co., 461 F.2d 506 (6th Cir.), cert. denied, 409 U.S. 1001 (1972).

Note that prior FCC determination does not technically work a collateral estoppel in the civil action, since the FCC has no power to adjudicate antitrust violations. United States v. RCA, 319 U.S. 190, 222-24 (1943). See also IT\&T v. AT\&T, 444 F. Supp. 1148 (S.D.N.Y. 1978); First Del. Valley Citizens TV, Inc. v. CBS, 398 F. Supp. 917 (E.D. Pa. 1975) (no power in the FCC to decide antitrust issues).

63. 422 U.S. 659 (1975).

64. Id. at 689 n.13; Comment, Antitrust and the Regulated Industries: The Panagra Decision and Its Ramifications, 38 N.Y.U. L. REv. 593, 611 (1963).

65. See Carnation Co. v. Pacific Westbound Conference, 383 U.S. 213, $221-22$ (1966) (discussed at text accompanying notes $92-94$ infra). 
immunity, as such authority may be preserved by use of nonexclusive, primary jurisdiction referral. That is, an antitrust court may refer to the FCC the question of the reasonableness of a tariffed rate or practice, without dismissing the action. Thus, the availability of primary jurisdiction referra ${ }^{66}$ vitiates the necessity rationale for imphed immunity. Immunity is not required to make the Commumications Act work, unless the FCC has previously approved the challenged practice. ${ }^{67}$

\section{B. Pervasive Regulatory Scheme}

The pervasiveness of the regulatory scheme may be a distinct criterion for immunity, or it may be only an indicator of the "plain repugnancy" of antitrust law to a detailed regulatory scheme. ${ }^{68}$ Although it has never served as the sole basis on which the Supreme Court has implied immunity ${ }^{69}$ the criterion is often pleaded. The notion that antitrust immunity should accoinpany a pervasive regulatory scheme may be grounded on the idea that extensive rate regulation shows a congressional intent to replace inarket inechanisms with administrative decisions. Where the market has been displaced, antitrust law is irrelevant. Since its purpose is to maintain competitive market mechamsms, antitrust law may be seen as antithetical to the pervasive regulatory regime, and therefore congressional imtent to repeal antitrust law im that area reasonably could be implied. Properly applied, this reasoning suggests that it is the intent of Congress, not the extent of regulation, that the courts should consider when asked to grant antitrust immunity.

The pervasiveness criterion originated in United States $v . R C A{ }^{70}$ The United States alleged that RCA had threatened to withhold television network affiliation in order to coerce an exchange of stations. RCA offered the defense that the exchange had been approved by the

66. See note 57 supra.

67. If the antitrust court making the primary jurisdiction referral of a crucial issue accepts the agency findings as conclusive, how does the result differ from immunity? First, if the agency finds the conduct unreasonable, the antitrust court will be able to grant damages to mitigate the mjury, a remedy which the FCC is not enpowered to award. See note 43 supra. Second, antitrust enforcement will further FCC policy in an area where a policy choice favoring competition has already been made and where the Commission is unable to remove existing positive incentives to anticompetitive beliavior. See notes $35-50$ and accompanying text supra.

68. See United States v. RCA, 358 U.S. 334, 350 (1959) (dicta); Shenefield, supra note 64, at 5. For a criticism of the criterion, see Comment, supra note 64, at 601-02.

69. See Comment, supra note 37, at 83-84. The later cases of Gordon v. New York Stock Exch., Inc., 422 U.S. 659 (1975), and Umited States v. National Ass'n of Sec. Dealers, lnc., 422 U.S. 694 (1975), did not clarify the ambiguity. See Comment, AT\&T and the Antitrust Laws: A Strict Test for Implied Immunity, 85 Y ALE L.J. 254, 257 (1975) (distinguishing the rationale of Gordon and NASD from the rationale of the pervasiveness inquiry). See also Gordon v. New York Stock Exch., Inc., 422 U.S. at 689 ("[W]hether the Exchange Act amounts to pervasive legislation ousting the antitrust acts is not a question before us").

70. 358 U.S. 334 (1959). 
FCC. The Court found that broadcast licensing regulation under the Communications Act was not pervasive, denied the request to dismiss on the ground that the FCC lacked sole jurisdiction over the exchange of stations, and refused to give collateral estoppel effect to the actual prior approval. The Court distinguished early primary jurisdiction cases where dismissal accoinpanied referral to the agency by asserting that regulation of broadcast licensees, unlike that of common carriers, is not pervasive. ${ }^{71}$ Because of this language, $R C A$ is frequently cited for the proposition that telecommunications common carriers are "pervasively" regulated and therefore immune froin antitrust prosecution. ${ }^{72}$

But this interpretation reads the case inuch too broadly. $R \dot{C} A$ merely declares that in the absence of pervasiveness, even actual approval should not be accorded collateral estoppel effect. $R C A$ was not an implied immunity case. Defendants only claimed estoppel froin an actual prior approval, not immunity from antitrust liability. ${ }^{73}$ Similarly, the early primary jurisdiction cases distinguished in $R C A$ did not address the immunity issue, but only required referral to the agency of the rate' reasonableness question because of the pervasiveness of the rate regulation. ${ }^{74}$ The Court even stated that the antitrust case could be refiled later if appropriate, suggesting that immunity would not be found. ${ }^{75}$

Otter Tail Power Co. v. United States ${ }^{76}$ teaches that the pervasiveness of a regulatory regime is insufficient to accord an industry immunity from antitrust liability if the behavior coinplained of was mitiated voluntarily. Otter Tail was an electric coinpany subject to both federal and state regulation. In a civil antitrust suit, the government coinplained of Otter Tail's refusals to interconnect facilities with municipal power companies, to wholesale electricity to thein, or to "wheel" (i.e.,

71. See id. at 348-50 (distinguishing Far East Conference v. United States, 342 U.S. 570 (1952), and United States Navigation Co. v. Cunard S.S. Co., 284 U.S. 474 (1931)). In these two cases, prices were regulated under the Shipping Act in a manner similar to their present regulation under the Communications Act. Under both regulatory schemes, there is a common carrier duty to serve customers at reasonable rates. Reasonable rates are enforced by requiring filing of privately set rates with the agency (FCC or Federal Maritime Commission), with the rates to go into effect unless disapproved. Compare Shipping Act of 1916, 46 U.S.C. $\$ \S 801-842$ (1976) with Coininunications Act of 1934, 47 U.S.C. $\$ \$ 151-609$ (1976). In each case the Court dismissed the antitrust cause of action and referred the disputes to the Federal Maritime Commission.

72. Comment, supra note 69, at 259 n.28 (1975).

73. 358 U.S. at 338.

74. Far East Conference v. United States, 342 U.S. at 573-74; United States Navigation Co. v. Cunard S.S. Co., 284 U.S. at 482.

75. Far East Conference v. United States, 342 U.S. at 577. See L. JAfFe, Judicial ConTROL OF ADMINISTRATION AGENCIES 132 (1965) (concluding that Far East was a case of referral, not immunity). Cunard was later limited by Carnation Co. v. Pacific Westbound Conference, 383 U.S. 213 (1966). See discussion of Carnation at text accompanying notes 92-94 infra.

76. 410 U.S. 366,373 (1973). 
transmit power purchased elsewhere along their lines) to the municipals. The Otter Tail Court found that because the Federal Power Act (FPA) preserved voluntary action by industry actors, the regulatory scheme was not intended to substitute for the antitrust laws. ${ }^{77}$

Like the FCC, the Federal Power Commission (FPC) has the authority to review and reject tariffed rates and practices, and to order interconnection. ${ }^{78}$ The Communications Act, however, contains language creatimg a common carrier duty to serve all at reasonable rates. The Otter Tail Court noted the absence of such language in the Federal Power Act, and seeins to have assumed that there would be sufficient pervasiveness of regulation to give rise to immunity if the FPA scheme had designated imdustry actors as common carriers. ${ }^{79}$ This does not follow from the logic of the decision, however. As long as the action coinplained of is voluntary in the first instance, antitrust law should apply. Thus, under the rationale of Otter Tail, there should be no antitrust immunity for the telecommunications industry. ${ }^{80}$

Otter Tail was a government suit that requested only injunctive relief; the Court may have been nore willing to find voluntary action in that context, even where there was regulatory power to coinpel action, than it would be where the defendant faced damage claims. However, lower courts have rejected the pervasiveness claim to immunity in dainage suits as well. ${ }^{81}$ Only im cases where there has been actual prior approval upon which the defendant justifiably relied, does fairness dictate that dainages should be precluded. ${ }^{82}$

One circuit has suggested that even if immunity is demed, the existence of the regulatory power inay affect the ultimate determination of antitrust liability. In Mid-Texas Communications Systems $v$. $A T \& T,{ }^{83}$ the Fifth Circuit found that application of Otter Tail to a

77. Id.

78. Id. at 371 (the FPC had authority to compel imterconnection). Compare 47 U.S.C. $\$ \S 201-205$ (1976) (FCC empowered to review rates and practices and to order interconnection).

79. "Congress rejected a pervasive regulatory scheine . . . in favor of voluntary coinmercial relationships . . . governed in the first instance by business judgment and not regulatory coercion ...." 410 U.S. at 374.

80. See Essential Coin. Sys., Inc. v. AT\&T, 610 F.2d 1114 (3d Cir. 1979) (denial of inmunity for carrier activity pursuant to a tariff which the FCC had taken under study but had not expressly approved). See also Litton Sys., Inc. v. Southwestern Bell Tel. Co., 539 F.2d 418 (5th Cir. 1976) (claim of unfair tying and predatory rates need not be granted state action immunity or be referred on primary jurisdiction to state regulatory agency since pricing policies are the result of utility's initiative); Jarvis v. AT\&T, 481 F. Supp. 120 (D.D.C. 1978).

81. See City of Mislrawaka v. Indiana \& Mich. Elec. Co., 560 F.2d 1314 (1977) (apphication of Otter Tail to allegations of rate squeeze by electric utility with harmful effect on retail coinpetitors).

82. See text accompanying notes $60-64$ supra.

83. 615 F.2d 1372 (5th Cir. 1980). 
carrier, with no regard for the existence or impact of regulation, might not be fair im the case of a regulated telephone company. The court concluded, however, that the existence of the regulatory scheme did not bring immunity as a matter of law. ${ }^{84}$ Instead, the jury should be instructed as to the existence and scope of regulation, and it should be permitted to consider this as bearing on the factual questions of monopoly power and the reasonableness of the company's refusal to deal. ${ }^{85}$

The adequacy of agency reniedies for anticompetitive behavior may be viewed as an indicator of the pervasiveness of the regulatory regiine, or as an independent determinant of immunity. In Pan American World Airways, Inc. v. United States, ${ }^{86}$ a suit charging an anticompetitive agreement to allocate territory between airlines, the Court held that the antitrust laws were displaced by the Federal Aviation Act. In spite of an express statutory immumity in the regulatory act, ${ }^{87}$ the Court refused to determine that antitrust law was entirely mapplicable to the airline industry ${ }^{88}$ Nevertheless, the Court decided that, since territory allocation was one of the inajor functions Congress intended the Civil Aeronautics Board (CAB) to perforn, section 1384 of the Act contemplated a limitation of competition and gave the Board jurisdiction over unfair inethods of competition. ${ }^{89}$ The CAB could both evaluate the effect of the agreenient on competition and provide an adequate remedy (divestiture); ${ }^{90}$ accordingly, the Court found that the Federal Aviation Act did effectively substitute for the antitrust laws in this industry. ${ }^{91}$

The unavailability of an effective administrative remedy played a part in Carnation Co. v. Pacific Westbound Conference. ${ }^{92}$ Plamtiff Carnation was a shipper who filed a treble damage antitrust action alleging that defendant maintained, from 1957 to 1962, a rate increase never approved by the Federal Maritime Commission. The Supreme Court reversed a dismissal of the action and remanded for a stay pending appeal of a Federal Maritime Commission finding in a parallel pro-

84. Id. at $1380-81$.

85. Id. at 1389. Anothcr panel in the Fifth Circuit has suggested in dicta that it will be more difficult to prove monopoly power in a regulated market. Alemda Mall, Inc. v. Houston Lighting \& Power Co., 615 F.2d 343, 354 (5th Cir. 1980). Alemda Mall, however, concerned a plaintiff whoin the court characterized as a customer, rather than a competitor, and who consequently lacked antitrust standing.

86. 371 U.S. 296 (1963).

87. See id. at 304 for a discussion of $\S 414$ of the Civil Aeronautics Act.

88. 371 U.S. at 304-05.

89. Id. at 309.

90. Id. at 312 .

91. Id. at 313 .

92. 383 U.S. 213 (1966). 
ceeding that the rates were unapproved. The Court held that plaintiff's rights under antitrust law were unaffected, even though the Shipping Act provided for reparations of overcharges paid under rates set pursuant to an unapproved conference agreeinent, and Carnation had not sought reparations in the Commission proceedings. ${ }^{93}$ Carnation could choose either the agency or the antitrust remedy. The Court may have allowed Carnation this option because reparations are a poor substitute for treble dainage hability. ${ }^{94}$ The damage reinedy under the Communications Act is similarly inadequate, being limited to refunds of customer overpayınents. ${ }^{95}$ As refund hability insufficiently deters overcharges, Carnation supports apphication of antitrust law to telecommunications as well as to shipping. ${ }^{96}$

93. Id. at 224 .

94. Litton Sys., Inc. v. Southwestern Bell Tel. Co., 539 F.2d 418 (5th Cir. 1976) (alternative holding interpreting Carnation). See also Mt. Hood Stages, Inc. v. Greyhound Corp., 555 F.2d 687 (9th Cir. 1977), vacated and remanded, 437 U.S. 322 (1978) (on unrelated statute of linitations issue).

However, one court has thought reparations inight be an adequate remedy. The court in McLeran v. El Paso Natural Gas Co., 357 F. Supp. 329 (S.D. Tex. 1972), aff d without opinion, 491 F.2d 1405 (5th Cir. 1974), found that the Federal Power Act, which contained rate review and reparations provisions similar to those in the FCC Act, was pervasive with respect to an antitrust suit alleging harm to the plaintiff class of consumers in the form of overcharges. The Court looked at the cuinulation of powers and controls and found immunity. Those powers included the ability to order a refund for overcharges. The Act, therefore, arguably provided an adequate remedy for the harm alleged.

But, for example, where consuners are indirectly injured by anticompetitive beliavior that damages a competitor's abihty to stay in the inarket, neither the Federal Power Act nor the Communications Act include the ability to provide a remedy. Where the Communications Act's remedies are inadequate, it slould be neither pervasive nor immunizing. See MCI Telecom. Corp. v. AT\&T, 462 F. Supp. 1072, $1098-99$ (N.D. 111), aff'd sub nom. AT\&T v. Grady, 594 F.2d 594 (7th Cir. 1978), cert. denied sub nom. AT\&T v. MCI Telecom. Corp., 440 U.S. 971 (1979) (no immunity in the absence of affirmative sanction by the FCC).

95. See note 43 supra.

96. The absence of adequate Communications Act reınedies for competitive abuses witlin the telecommunications industry unight be thouglit to show congressional intent to preserve antitrust law. But this inay be a fiction. Congress may simply not have foreseen future competitive abuses against which to design agency remedies. For example, the 1934 Communications Act contains provisions to protect local telephone operating coinpanies froin the major competitive abuse of its time, the refusal to interconnect. 47 U.S.C. $\$ 10$ (1976). See generally Gable, The Early Competitive Era in Telephone Communication, 1893-1929, 34 LAw \& CONTEMP. PROB. 340, 350, 353-54 (1969) (Bell System's refusal to interconnect has contributed to failure of many local telephone operating companies). But failing to foresee the radical clianges in technology and the possibilities for a competitive industry structure, the Act's rate approval provisions are directed only at protecting custoiners from overcharges, not at protecting coinpetition. See 47 U.S.C. $\$ \$ 204-209$ (1976) (placing the burden of proof on the carrier to justify increased charges and providing reparations power in the FCC to remedy overcliarges). Whatever the original intent of Congress, the application of antitrust reinedies is of practical value to aid an outmoded regulatory unodel in dealing with current industry structure. See text accompanying notes $\mathbf{4 2 - 5 0}$ supra. 


\section{Self-Regulatory Scheme}

In Gordon v. New York Stock Exchange, Inc., ${ }^{97}$ the Court held that antitrust law does not apply to rate fixing on the securities exchanges. The unanimous Court based immunity on both the intent of the securities acts to allow supervised self-regulation by the exchanges and the existence of an actual SEC rule in confliet with antitrust standards. ${ }^{98}$ In the companion case, United States v. National Association of Securities Dealers, Inc. ${ }^{99}$ (NASD), no existing rule created a conflict with the per se antitrust rule against price fixing. The five-member majority of the Court based immunity solely on the generally self-regulatory scheme of the securities acts. ${ }^{100}$

Since $N A S D$ seems to extend immunity beyond acts that are actually compelled, ${ }^{101}$ some commentators have regarded these two cases as breathing new life into the pervasiveness doctrine. ${ }^{102}$ But this view is erroneous. ${ }^{103}$ A doctrinal distinction can be niade between the scope of antitrust immunity under a self-regulatory scheine as opposed to an agency-governed regulatory scheme.

In the creation of self-regulatory schenies, Congress has allocated important decisions to private industry groups that must be expected to act $\mathrm{m}$ their own interest to create, rather than be constrained by, market conditions. Thus, important private decisions are made im concert rather than conipetitively. Those decisions should not be subject to antitrust law. By contrast, the purpose of agency regulation is often to correct for niarket imperfections, such as nionopolistic structure, insuf-

97. 422 U.S. 659 (1975).

98. Id. at 675 (the SEC had promulgated a specific rule governing transition from fixed to competitive rates).

99. 422 U.S. 694 (1975).

100. Id. at 729-30.

101. See Northeastern Tel. Co. v. AT\&T, 477 F. Supp. 251 (D. Conn. 1978) (distimguishing Gordon and NASD). Compare Otter Tail Power Co. v. United States, 410 U.S. 366 (1973) (pervasiveness of a regulatory scheme is insufficient to accord an industry immunity from antitrust hability if action complained of was initiated voluntarily) (discussed at notes 76-84 and accompanying text supra) with $N A S D$ and Gordon.

102. See Comment, SEC Regulation as a Pervasive Regulatory Scheme-Implied Repeal of the Antitrust Laws with Respect to National Securtites Exchanges and the NASD, 44 FORDHAM L. REv. 355, 356 (1975).

103. Antitrust immunity for the self-regulated national securities niarket was suggested in Silver v. New York Stock Exch., Inc., 373 U.S. 341 (1963), where the Court intiniated that a selfregulatory scheme that included sone type of agency check on exchange actions could confer immunity, although the particular action at issue in that case did not qualify for immunity. Silver preceded Otter Tail, but the Otter Tail Court did not equate voluntary action with self-regulation or find an immunity under the Silver theory. Thus, voluntary action should not be immunized from antitrust law sinply because the agency subsequently acquiesces or because it regulates many other aspects of firm conduct. The Gordon/NASD exenuption is generally inapplicable to telecommunicatious and other industries governed by a combination of voluntary action and agency regulation. 
ficient consumer information, and inadequate territorial coverage. To the extent that the agency actually supplants the market by compelling activities, there is immunity. ${ }^{104}$ But creation of a regulatory agency does not by itself indicate a choice to displace the market competition. To the extent a sphere for voluntary action by industry actors remams, the inarket has not been displaced, and therefore the discipline of antitrust law should remain. A pervasively self-regulated industry, then, might arguably require broader antitrust immunity than an industry allowed a great deal of voluntarimess under an agency-regulation scheine.

Unlike the securities laws, ${ }^{105}$ the Communications Act allocates no quasi-official power to a private industry group. Telecommunications are instead regulated like inost public utilities, where agency regulation preserves aspects of the market but seeks to correct malfunctions caused by capital-intensive, natural monopoly market structure. Private firms exercise voluntary conduct within bounds, but are not authorized to coordmate their activities by self-regulation in derogation of the market. Thus, the telecommunications industry does not qualify for antitrust immunity under a self-regulatory scheme rationale.

III

\section{PRIMARY JURISDICTION}

Applying the antitrust laws to a regulated industry has two potential results. First, it may substitute the court for the agency as decisionmaker on the factual and legal questions, and second, it may provide a damages reinedy not otherwise available from the agency. But neither of these results follows automatically from the no-immunity decision. Part IV will discuss how the regulatory scheme may limit the apphication of antitrust reinedies, mcluding damages. The present discussion explores primary jurisdiction, a procedural doctrine that may send to the agency material questions in the antitrust hitigation, even when there is no immunity.

The doctrine of primary jurisdiction was developed by the courts in the interests of comity and decisionmaking efficiency. Exercising its discretion, ${ }^{106}$ a court inay refer issues to the regulatory ageney. The referral directs the parties to seek an agency determination and often stays the judicial proceedings pending that determination. ${ }^{107}$

While courts commonly assert that they are not bound by agency

104. See Gordon v. New York Stock Exch., Inc., 422 U.S. 659 (1975).

105. 15 U.S.C. \& 78s(b) (1971) (allocating ruleunaking power to the securities exchanges).

106. See note 109 infra.

107. See Carter v. AT\&T, 365 F.2d 486, 496 (5th Cir. 1966), cert. denied, 385 U.S. 1008 (1967). 
legal determinations, ${ }^{108}$ the status of agency factual determinations is unclear. If referral is based upon relative judicial incompetence, it would be illogical not to accord great weight to agency factual findings. Moreover, deference to an agency's factual or even legal conclusions may be desirable to avoid irreconcilable conflicts between antitrust law and the regulatory scheine. For exainple, if the FCC, under its standards, justifies conduct that simultaneously offends antitrust standards, denying conclusive effect to the FCC's findings may create the requisite irreconcilable conflict that calls for implied immumity from the antitrust laws. ${ }^{109}$ Thus, probable judicial deference to the agency determination after referral inakes the question of whether to refer the crucial one.

\section{A. Delay, Cost, and Choice of Forum}

Referral may vitiate the value of an antitrust cause of action because it adds to delay, increases costs, and deprives plaintiffs of what may be perceived as the more convenient or sympathetic foruun. Courts sliould consider the additional costs of delay in determining whether to refer. ${ }^{10}$ Soine courts have atteinpted to mitigate the delay problem by conditioning referral on agency response within a limited period of time. In Newark v. Delmarva Power \& Light Co., the court

108. See Ricci v. Chicago Merc. Exch., 409 U.S. 289, 307 (plurality opinion) ("We make no clain that the Commission has authority to decide . . . the question of immunity . . . ."). Also note the concurrence of Chief Justice Burger: The Court's conclusion that the Commodity Exchange Commission "may materially aid in proper consideration of petitioner's antitrust claims ... should not be read to suggest that the Commission's resolution of the dispute either will or will not foreclose subsequent application of the antitrust laws." Id. at 308. See Carter v. AT\&T, 365 F.2d at 499 ("For the doctrine [of primary jurisdiction] applies even though the facts after they have been appraised by specialized competence serve as a premise for legal consequences to be judicially defined.") (quoting Far East Conference v. United States, 342 U.S. 570, 574 (1952)).

See also Mortensen v. First Fed. Sav. \& Loan Ass'n, 549 F.2d 884, 900 (3d Cir. 1977) ("That the appropriate administrative agency is given the first opportunity to categorize the factual issue here involved does not mean that its characterization will be binding on the federal court when it does consider the federal antitrust claim."); Kansas Power \& Light Co. v. Federal Power Comm'n, 554 F.2d 1178, 1184 (D.C. Cir. 1977) (concurrent jurisdiction, FPC not required to stay its proceedings since "[r]egardless of the Commission's disposition of this case, the District Court in Kansas is free to exercise its own judgment on the relevant antitrust issues.").

109. See Mississippi Power \& Light v. United Gas Pipe Line Co., 532 F.2d 412 (5th Cir. 1976), cert. denied, 429 U.S. 1094 (1977) (referral may not be discretionary when the issue is interpretation of a tariff, inplying that the agency's determination of a tariff would be conclusive). See also text accompanying notes 61-67 supra.

110. See Mississippi Power \& Light v. United Gas Pipe Line Co., 532 F.2d 412 (5th Cir. 1976), cert. denied, 429 U.S. 1094 (1977). See also City of Mishawaka v. Indiana \& Mich. Elec. Co., 560 F.2d 1314 (7th Cir. 1977), cert. denied, 436 U.S. 922 (1978) (no abuse of discretion where delay was one ground for denial of primary jurisdiction referral). But see Shenefield, Annual Survey of Antitrust Developments-The Year of the Regulated Industry, 31 WASH. \& LEE L. REV. 1, $57-58$ (1974) (criticizing Marshall's concern with delay in Ricci v. Chicago Merc. Exch., 409 U.S. 289 (1973)). 
agreed to await the Federal Power Commission determination in a parallel proceeding "unless the proceedings . . . are unduly delayed."111 In Macom Products Corp. v. $A T \& T,{ }^{112}$ the district court requested the Commission to compile and subunit its findings within seven months. In both cases the judicial action, then in the discovery stage, was not stayed pending agency action.

But time-conditioned referral may not solve the problem of delay. Simce the additional workload may interfere with the agency's internal priorities, the agency may refuse to decide the matter. If the goal of referral is to solicit the agency views only in the interests of comity, perhaps it is sufficient simply to offer the opportunity for agency response. If a timely agency response is not forthcoming, the court could then in good faith decide the matter. But if referral is necessary because a court is not competent to make required technical, factual determinations, substantial delay may be unavoidable because a set time limit is unenforceable. However, treble damage liability, which would continue to build during the suit, could lessen the incentive that otherwise exists for defendants to delay the agency determination by, for example, dragging their feet in assembling and submitting necessary data to the FCC.

Even if the imposition of a time constraint solves the delay objection to referral, referral will significantly increase the costs of antitrust litigation. Perhaps the relative sizes of the parties or the centrality of the issue to the lawsuit should be relevant to the decision to refer. In Macom Products, both parties appear to have been national firms and thus more likely to be able to bear the mcreased litigation costs. Plaintiff was suing AT\&T, GTE, and forty-one Bell and independent operating companies. Had it been suing carriers in its region only, referral might have been inadvisable because of the chilling effect of the added cost to parties less likely to be able to bear the burden. In Carter Electronics Corp. v. $A T \& T$, 113 the court referred a tariff question to the FCC only after finding that it was a central issue $\dot{n}_{1}$ the antitrust case. Referral is not necessary when the agency's findings would be of secondary importance in determining the antitrust issues. ${ }^{114}$

But referral should not be systematically avoided because it deprives the plaintiff of his or her chosen forum. Antitrust law is not a

111. 467 F. Supp. 763, 772 (D. Del. 1979).

112. 359 F. Supp. 973 (C.D. Cal. 1973).

113. 365 F.2d 486, 492 (1966) ("the tariff is inescapably at the center of this controversy"). See also Mississippi Power \& Light v. United Gas Pipe Line Co., 532 F.2d 412 (5th Cir. 1976), cert. denied, 429 U.S. 1094 (1977).

114. Local 189, Amalg. Meat Cutters v. Jewel Tea Co., 381 U.S. 676, 686 (1965); Mississippi Power \& Light v. United Gas Pipe Line Co., 532 F.2d 412 (5th Cir. 1976), cert. denied, 429 U.S. 1094 (1977). 
tool by which judges can or should singlehandedly reform or displace the regulatory process. . Referral should be narrowly available to avoid the chilling effects of delay and increased costs, but it cannot be dispensed with altogether. The availability of the primary jurisdiction referral is at least sometimes necessary to avoid irreconcilable conflicts of the antitrust laws with the regulatory scheme. ${ }^{115}$ In some instances the court will not be able to determine whether an irreconcilable conflict exists unless it refers the case to the agency. Where there is no important question of irreconcilability, however, referral should be limited to those factual questions that the court is markedly less competent than the agency to decide.

\section{B. Policymaking Authority and the Relative Expertise of Courts and Agencies}

This Comment has suggested that cost, delay, and the centrality of the issue to be referred in the antitrust suit should bear on the decision whether to refer. The case law emphasizes two other factors, however: the need to preserve agency policymaking authority and the relative competence of the court and the agency. The early case of Texas \& Pacific Railroad v. Abilene Cotton Co. ${ }^{116}$ evinces both concerns. In a civil action by a shipper alleging overcharges, the Court required the parties to refer to the Interstate Commerce Commission (ICC) the question of the reasonableness of rates, in spite of an express statutory clause preserving a civil cause of action. Referral was considered necessary to preserve the ICC as the sole decisionmaker regarding rates. ${ }^{117}$ The ICC was also considered to be the only forum competent to decide the issue of rate reasonableness. ${ }^{118}$

In Ricci v. Chicago Mercantile Exchange, ${ }^{119}$ the Supreme Court upheld referral to the Commodity Exchange Commission of the issue whether Exchange rules had been violated. Referral was considered appropriate because it would "Inaterially aid" the lower court in subsequently deciding the immunity question, ${ }^{120}$ and not because the court was thought to be relatively incompetent. The issue of interpretation

115. See notes 61-67 and accompanying text supra.

116. 204 U.S. 426 (1907).

117. $I d$ at 448 .

118. Id. It has been suggested that the expertise and uniformity rationales are grounded primarily im judicial deference to Congress' designation of the regulatory agency as the main federal decisionmaker with respect to the industry. Comment, Primary Jurisdiction: A General Theory and Its Application to the Securities Exchange Act, 63 CALIF. L. REv. 926, 936-37 (1975).

119. 409 U.S. 289 (1972).

120. Id. at 305. The Court left undecided whether immunity would follow if the rules had not been violated. However, Gordon, 422 U.S. 659 (1975), and NASD, 422 U.S. 694 (1975), see text accompanying notes 97-105 supra, might now exempt the conduct complained of in Ricci from antitrust scrutiny. 
and application of the published rules of the Exchange is unlikely to have been so complex that a court would be incompetent to decide it. ${ }^{121}$

Ricci does not imply that referral is to be preferred whenever both forums are competent to deal with the question. Rather, Ricci sliould suggest that referral is favored with respect to industries within selfregulatory regimes, because industry behavior generally falls within the self-regulatory exemption from antitrust law. ${ }^{122}$ The plaintiff in Ricci alleged conspiracy by the Exchange and others. Yet the Exchange had been set up to facilitate cooperative decisionmaking or conspiracy, and this function has been recognized by the regulatory scheme. ${ }^{123}$ Thus, with respect to a self-regulatory scheme, primary jurisdiction to preserve the statutory decisionmaker may make sense even where the technical complexity of the question does not necessitate referral. ${ }^{124}$ But since the Communications Act did not establish a self-regulatory scheme, ${ }^{125}$ special deference to the FCC through automatic referral is not justified. Outside self-regulatory schemes, primary jurisdiction referral generally sliould not be granted. Referral for primary jurisdiction is a tool to promote proper and efficient accommodation between the courts and administrative agencies, ${ }^{126}$ not a tool to clear judicial dockets. Indiscriminate referral serves neither fairness nor efficiency. Referral requires a party to imitiate a new proceeding, with attendant cost and delay, both in obtaming the determination and defending it through the levels of judicial review. ${ }^{127}$ Therefore, referral should be made only when there is an important issue that the court is imcompetent to decide. Recent case law supports this view. In Nader v. Allegheny Airlines, Inc. ${ }^{128}$ the Supreme Court unanimously upheld refusal

121. See Comment, supra note 118 , at 950.

122. 409 U.S. at 301-02; see Litton Sys., Inc. v. Southwest Bell Tel. Co., 539 F.2d 418 (5th Cir. 1976). But see 409 U.S. at 308 (Burger, C.J., concurring), indicating that the decision to refer did not depend upon the possibility of immunity.

123. See note 105 supra.

124. This follows from the nature of a self-regulatory scheme: By creating a self-regulatory scheine, Congress has left important decisions to an industry group, which can be expected to act in its own interest and to create, rather than be constrained by, market conditions. Congress has arguably made a decision to allow nonmarket choices by its selection of the private decisionmaker. On the other hand, the purpose of agency regulation is often to correct for market imperfections such as natural monopoly, insufficient supply for certain market sectors or populations, and imperfect information in the form of deceptive advertising. Thus, agency regulation, unlike self-regulation, may not be a positive choice to supplant the inarket.

125. See text accompanying note 105 supra.

126. Botein, Primary Jurisdiction: The Need for Better Court/Agency Interaction, 29 RuTG. L. REv. 867, 876-77 (1976). See also Mississippi Power \& Light v. United Gas Pipeline Co., 532 F.2d 412 (5th Cir. 1976), cert. denied, 429 U.S. 1094 (1977) (discussing prinary jurisdiction as one inethod to integrate the regulatory agency into the judicial decisionmaking process).

127. See also Ricci v. Chicago Merc. Exch., 409 U.S. 289, 309, 320 (1972) (Douglas, J., dissenting) (raising due process considerations).

128. 426 U.S. 290 (1976). 
to refer to the $\mathrm{CAB}$ the question of whether airline overbooking constituted misrepresentation. ${ }^{129}$ Ignoring the preservation-of-decisionmaker rationale, the Court said that since misrepresentation is a matter within judicial competence, referral was not required. ${ }^{130}$ The possibility of interference with $\mathrm{CAB}$ pohcynaking was dismissed by noting that the $\mathrm{CAB}$ had no rule forbidding or requiring overbooking, but only rules requiring priorities and compensation when carriers did practice overbooking. ${ }^{131}$ Noting an express clause in the CAB Act preserving common law and statutory actions, ${ }^{132}$ the Court found that concurrent jurisdiction had been conteinplated at passage. Further, the Court found that the issues did not turn on "a determination that could be facilitated by an informed evaluation of the economics or technology of the regulated industry." "133 Thus, even though the CAB had rate review authority similar to that of the FCC, and the Court's award of compensatory and punitive damages affected $\mathrm{CAB}$ rate policy by affecting the airline's costs of doing business, ${ }^{134}$ the Court rejected referral.

Nader inakes expertise the dominant rationale for discretionary primary jurisdiction referral, apparently recognizing the agency as the automatically preferred decisionmaker only where there is a tariff at

129. But see Writers Guild of Am., W., Inc. v. American Broadcasting Corp., 609 F.2d 355 (9th Cir. 1979), petition for cert. fled, 49 U.S.L.W. 3103 (U.S. Aug. 26, 1980) (No. 79-1717) (referral to FCC although court not incompetent to decide the issue.)

130. Id. at 303-06.

131. Id. at 306-07 (CAB rule only required carriers to prounulgate priority bunping plans and to compensate bumped passengers).

132. Since the Communications Act also contains a preservation or saving clause, 47 U.S.C. $\S$ 414 (1976), Nader implies telecommunications cases should not be referred to the FCC. But reliance on the preservation clause alone is probleinatic. The Act contains one express antitrust exemption for mergers or consolidations approved in advance by the FCC. 47 U.S.C. $\$ 221$ (1976). The saving clause plus this one narrow exemption could indicate that no other exemptions fron antitrust were intended. However, like most of the 1934 Communications Act, the saving clause was transferred unchanged front the Interstate Commerce Commission Act. Compare 47 U.S.C. $\S 414$ (1976) with 49 U.S.C. $\$ 10103$ (Supp. II 1978) (formerly $\S 22(1)$ ). Consequently, there may have been little conscious intent behind the addition of the provision. Moreover, even though the ICC Act was never thought to exempt the railroads from antitrust liability (some of the earliest Sherman Act cases were directed against the great rail monopolies), it was early held that the saving clause in the ICC Act was not authority for a separate decisionmaker on the reasonableness of rates. Texas \& Pac. R.R. v. Abilene Cotton Oil Co., 204 U.S. 426 (1907). Since Congress adopted the ICC Act's saving clause without modification when it passed the Communications Act, it may be inferred that it adopted the Abilene Cotton interpretation as well. Therefore, referral of an issue of rate reasonableness would be in order under the Communications Act. See T.I.M.E., Inc. v. United States, 359 U.S. 464, $472-74$ (1959) (applying this line of reasoning to the Motor Carriers Act). On the other hand, Abilene Cotton was concerned about the potential for abuse of nonuniform rail rates in the early 1900's, a problem of far less magnitude in modern telecommunications. See 204 U.S. at $439-40$.

133. 426 U.S. at 305.

134. A carrier could pay damages or discontinue the practice and risk lower load factors. Each option affects the cost of doing business. 
issue. ${ }^{135}$ The existence of a tariff not only indicates a situation where expertise may be necessary, but may also signal a need to avoid irreconcilable conflict. ${ }^{136}$

\section{Exemplary Referral Situations}

If the FCC has no power to approve the allegedly anticompetitive activities and no technical expertise is required to evaluate claims of anticonpetitive conduct, there is no reason for referral. For example, where the alleged anticoinpetitive conduct is comprised of shain or dilatory proceedings before the FCC, there would be no referral. The court can decide these claims, with the attendant Noerr/Pennington defenses, ${ }^{137}$ without interfering with the regulatory agency's pohicymaking and without the need for its expertise.

Where the FCC has authority over a practice and has not authorized conduct that antitrust law would condemn, there should be no referral unless there are technical factual questions. Consider, for example, an alleged refusal to allow installation of customer-supphed equipinent in the face of FCC policy requiring full interconnection rights for all registered equipment. Simce antitrust law also condemns refusals to deal, the antitrust courts would be helping to enforce FCC policy by hearing the case. Referral might weaken that aid, since the extra cost and delay could make these suits less common. Furthermore, agency expertise is not required in order to answer the factual question of whether the equipment has been registered with the FCC.

By contrast, where the plaintiff challenges an established industry practice covered by filed tariffs, deference to both the agency's policymaking authority and its expertise suggests referral. ${ }^{138}$ For example, the issue of whether a rate is predatory nust be referred to the FCC..$^{139}$

135. 426 U.S. at 304-05 \& n.13.

136. See text accompanying notes 61-67 supra.

137. United Mine Workers v. Pennington, 381 U.S. 657 (1965); Eastern R.R. Presidents Conference v. Noerr Motor Freight, lnc., 365 U.S. 127 (1961). These two cases defined an antitrust exemption for certain attempts to influence legislation or otherwise petition the government.

138. See United States v. Homestake Mining Co., 595 F.2d 421 (8th Cir. 1979); text accompanying notes 116-32 supra.

Soine courts would narrow referral even when a tariff is at issue. United States v. Open Bulk Carriers Ltd., 465 F. Supp. 159 (S.D. Ga. 1979) denied primary jurisdiction referral, stating: " "[T] here would be no need to refer the matter of construction to the [Federal Maritime] Commission if that body, in prior releases or opinions, has already construed the particular tariff at issue, or has clarified the factors underlying it.' "Id. at 164 (quoting United States v. Western Pac. R.R., 352 U.S. 59, 64 (1956)). " "[T] he attainment of uniformity does not require that in every case where the construction of a tariff is in dispute, there shall be a preliminary resort to the Coinunission." " Id. at 165 (quoting Great N. Ry. v. Merchants Elev. Co., 259 U.S. 285, 291 (1922)). The Open Bulk court did admit that referral would be necessary where there was occasion for admimistrative discretion.

139. The FCC does not determine whether a rate is predatory, but whether it is reasonable. It 
The actual task of determining whether a rate is below cost requires expert processing of masses of data through the concepts and inethods of fully distributed costing, separations, and joint cost allocation; this is a task in which the FCC is especially experienced. If the court were to hear the issue, on the other hand, the trial would consist of a battle of economists. ${ }^{140}$ Thus, referral would achieve overall efficiency in the settleinent of disputes concerned with this technical issue. ${ }^{141}$

\section{IV \\ REMEDY}

Applying antitrust law to regulated carriers is useful even where crucial factual issues are mitially decided by the agency on referral. The availability of treble dannages provides a cure for the positive incentive to delay agency proceedings or to violate standards and await detection. ${ }^{142}$ However, once it is determined that there is an antitrust hability, it is necessary to avoid a conflict between the judicial remedy and agency action.

\section{A. The Rate Structure Objection}

A plea for damages under antitrust law is subject to the objection that any award of damages would interfere with the rate structure set up by the FCC. ${ }^{143}$ This concern is at the heart of two early ICC cases denying that damages are available for claims based on allegations of unreasonable rates. Keogh v. Chicago \& Northwest Railway ${ }^{144}$ asserted three bases for holding that a private shipper could not sue to recover dainages for excessive rates. First, the rates had been approved by the ICC in proceedings to which plaintiff was a party. ${ }^{145}$ Second, the ICC was einpowered to give an adequate reparations reinedy to shippers overcharged by a carrier. ${ }^{146}$ And, third, to allow a shipper

will find a rate unreasonable if it is not cost-justified. Thus, the Commission might find a nonpredatory rate unreasonable, but it should not find a predatory one reasonable, since a predatory one is by definition below cost.

140. In other areas of antitrust law, the Burger Court has displayed confidence in the ability of lower federal courts to decide factual issues based on complex economic arguments. See, e.g., Continental T.V., Inc. v. GTE Sylvania, Inc., 433 U.S. 36 (1977) (comparison of effects on interbrand and intrabrand competition from vertical restriction). The choice in Sylvania, however, was between inore or less analysis, not between analysis by a more or less competent decisionmaker.

141. This apphies to unilaterally set rates. If the allegation is conspiracy to fix rates, referral may not be needed. The violation is the conspiracy, and reasonableness of the rates is no defense to a charge of price fixing. See Georgia v. Pennsylvania R.R., 324 U.S. 439 (1945).

142. See text accoinpanying notes $42-50$ supra.

143. This is the way the argument is phrased, but, in fact, the structure is set up by the carrier, subject to Commission approval of tariff filings. See note 43 supra.

144. 260 U.S. 156 (1922).

145. Id. at 160 .

146. Id. at 162-63. 
damages would, in effect, produce unequal rates, an event that would offend one of the major purposes of the ICC Act: the prevention of unjust discrimination and preferential pricing by carriers with respect to shipper-customers. ${ }^{147}$ In Georgia v. Pennsylvania Railroad, ${ }^{148}$ the Keogh no-damages rule was applied im an antitrust suit. Georgia, suing in parens patriae, alleged a conspiracy to fix high and discriminatory rates to the detriment of Georgia shippers. The Court allowed the cause of action for injunctive relief, but stated that under the doctrine of Keogh, no damages would be available. The tariffed rate "was for all purposes the legal rate as between shipper and carrier and may not be varied or enlarged either by the contract or [the] tort of the carrier ... because otherwise the paramount purpose of Congress-prevention of unjust discrimination-might be defeated." 149

Keogh and Georgia have been used by lower courts to deny treble damage liability to defendants im other regulated industries. In City of Newark v. Delmarva Power \& Light Co., ${ }^{150}$ excessive wholesale rates relative to retail rates was alleged as an antitrust violation. The plaintiff was a competitor, a municipal power company, rather than a custoiner, alleging a cause of action partly based on a tariffed rate. Keogh was cited in discussing the potential for conflict with the agency's "rate structure." 151 But this application of Keogh is much too broad. Preservation of nondiscriminatory, uniforin rates between customers, not preservation of a given "rate structure" as such, was the rationale for Keogh. If Keogh was truly concerned with the integrity of the rate structure in the abstract, it is difficult to see why the Supreme Court did not apply it in Nader $v$. Allegheny Airlines, Inc. ${ }^{152}$ and refuse the damage award there.

Even if an abstract rate structure concern is valid, its application need not extend beyond actions brought by customers. Furtler, the rate structure objection may be satisfied by allowing damages only after primary jurisdiction referral of the reasonableness question to the FCC. In Texas \& Pacific Railroad v. Abilene Cotton Oil Co., the Court required the plaintiff/shipper to take its complaint to the FCC. To avoid nonuniform rates and unfair advantages among shippers, a inajor goal of the Interstate Commerce Act, a single decisionmaker on rates was necessary. ${ }^{153}$ Subsequent cases have treated Abilene Cotton

147. Id. at 163 .

148. 324 U.S. 439 (1945).

149. Id. at 453.

150. 467 F. Supp. 763,769 (D. Del. 1979).

151. Id. at 770 .

152. 426 U.S. 290, 298-300 (1976); see text accompanying notes 129-36 supra (discussion of Nader).

153. 204 U.S. at 446. 
as a primary jurisdiction case, allowing the cause of action but sending the question of reasonableness to the agency. ${ }^{154}$ Since preserving the integrity of the rate structure is equivalent to preserving a single decisionmaker on rates, the rate structure objection is overcone by the use of primary jurisdiction. ${ }^{155}$ Once the FCC has decided a rate is unreasonable, the court can give dannages relief.

\section{B. Avoidance of Conflict}

The rate structure objection represents a valid concern that judicial remedies not conflict with past or future agency action. When a court and an agency have concurrent jurisdiction over an issue, one of them must defer to the other's remedial order.

\section{Agency Deference}

There are some instances where the agency seens to have the responsibility to defer. In California v. FPC, ${ }^{156}$ the Suprene Court based its decision on a principle of "reverse primary jurisdiction." The State of Cahifornia sought judicial review of the FPC's refusal to stay approval proceedings for a merger of two inajor natural gas producers pending the outcome of a prior Justice Department antitrust action against the merger. The Supreme Court ordered the FPC to stay its proceedings, observing that " $[t]$ he orderly procedure is for the Commission to await decision in the antitrust suit before taking action." 157 Similarly, in the remedy area one court has suggested a division of authority between courts and admimistrative agencies based on the primacy of the body first assuming jurisdiction of the inatter. In United States $v . N B C^{158}$ a district court, approving a consent decree regarding prime time procureinent practices, noted that proposed FCC rules would also deal with the subject. The court said that the burden would be on the Commission to forn rules which "[do] not conflict with outstanding judicial orders." 159 However, agency deference to prior judicially imposed remedies may not generally be appropriate, because it inay undercut the agency's policymaking authority. When the legisla-

154. T.I.M.E., Inc. v. United States, 359 U.S. 464, 473 (1959).

155. See Essential Com. Sys., Inc. v. AT\&T, 610 F.2d 1114 (3d Cir. 1979) (denying immunity and limitimg Keogh to customer/plaintiffs).

156. 369 U.S. 482 (1962).

157. Id. at 489 .

158. 449 F. Supp. 1127 (C.D. Cal. 1978) (approving consent degree).

159. Id. at 1139 . While logically attractive, this approach of deference to the first actor may be less available in a telephone suit. $N B C$ was a broadcasting case, not a common carrier one. The $N B C$ court, relying on $R C A$, pointed out that its order would not disrupt a rate structure. Further, the court would not be deterred from ordering appropriate relief by the mere fact of the Commission's inquiry. There the Commission's rules, if adopted, would be prospective. 
tive sclieme calls for the agency to develop regulatory policy in an area, it sliould be able to do so im the first instance. The responsibility to avoid conflict should not be placed exclusively on the agency.

\section{Judicial Deference}

Judicial deference to the agency in crafting a remedy may be appropriate im order to preserve the imtegrity of the agency's policyinaking authority. With respect to a number of regulated industries, the Supreme Court has avoided awarding any remedy that would interfere with an agency's policymaking authority. In Carnation Co. v. Pacific Westbound Conference ${ }^{160}$ the Court stayed an antitrust suit pending final Federal Maritime Commission determination of the reasonableness of the challenged rates on the ground that the Commission could decide to approve the rates prospectively. ${ }^{161}$ The Court did not wish to allow enjoinment of rates that the Commission unight subsequently approve. In Otter Tail Power Co. v. United States ${ }^{162}$ an electric power coinpany was enjomed froin refusing to sell or wheel power to inunicipal power coinpamies, but was not required to sell except at reasonable rates filed witli and subject to approval by the FPC in the usual fashion. Three dissenters argued that the order infringed the FPC's power to order interconnection. ${ }^{163}$ The nrajority sidestepped the question of whetler the order infringed FPC enforceinent power by noting that the FPC liad in fact ordered interconnection in a parallel proceeding. ${ }^{164}$ However, the Court considered that any future question of judicial interference with agency authority would arise only if there were an actual conflict between an FPC order and a court order. ${ }^{165}$ A potential conflict between the remedial powers of the agency and the judiciary was not sufficient to create an issue.

However, if there had been an actual conflict, the agency determination would liave certainly prevailed since Congress gave a clear statutory mandate to the FPC to decide whether involuntary interconnection is warranted. ${ }^{166}$ Therefore, to minimize conflicts between court and agency, courts should fashion remedies im consonance with agency policy. For exainple, injunctive relief slould be available

\footnotetext{
160. 383 U.S. 213 (1966).

161. Id. at 223.

162. 410 U.S. 366 (1973).

163. Id. at 395 (Stewart, J., concurring and dissenting). In Otter Tail, the FPC had also ordered interconnection in a parallel proceeding. This fact, howcver, was not necessary to the majority's decision that the Court had independent power to enjoin imterconnection.

164. Id. at 376.

165. Id. at 377 ("as, if, and when the Commission denies the interconnection and the District Court nevertheless undertakes to direct it").

166. Id. at 394-95 (Stewart, J., concurring and dissenting).
} 
if one carrier refuses to connect with another. The Communications Act creates a common carrier duty to interconnect that the FCC has specific authority to enforce. ${ }^{167}$ Additional court enforcement can only complement and support the FCC policy and its enforceinent role. If a reasonableness defense were raised based on teehnical questions about connection feasibility, that issue would be referred to the agency on primary jurisdiction. ${ }^{168}$

Similarly, dainages should be awarded so as to avoid interference with agency pohcyniaking power. Courts have argued that damages for past acts cannot logically interfere with the agency's authority, which is to regulate current and future activities. ${ }^{169}$ But where the construction or vahidity of a tariff is involved, as im allegations of predatory rates, dainages inay be available only after the FCC has declared the rate unreasonably low. ${ }^{170}$ Even where the activity is covered by a filed tariff, daunages should be available after there has been primary jurisdiction referral or other prior agency action. ${ }^{171}$

The equipinent cases are clearly instances where both injunctive

167. 47 U.S.C. $\$ \S 201-205$ (1976).

168. See text accompanying notes 116-36 supra.

A different type of reasonableness defense-that the action was based on a reasonable carrier interpretation of regulatory standards-was raised in Mid-Texas Com. Sys. v. AT\&T, 615 F.2d 1372 (5th Cir. 1980). AT\&T and its local operating company, Southwestern Bell, refused to assign an area code to Woodlands Telecoin. Corp., a joimt venture formed by Mid-Texas and a developer to serve a new suburban community. Woodlands made an informal complaint to the FCC, but withdrew it before the FCC inquiry was completed, since Southwestern Bell had captured the new market. Woodlands then filed a Sherman Act suit, alleging conspiracy to monopolize and restrain trade. Bell responded by claiming that its refusal to deal had been based on its conception of the regulatory "public interest" standard for interconnection, which was designed to avoid facihity duplication. The court denied immunity and primary jurisdiction, but said that the fact of regulation could be considered by the jury in assessing habihty and damages. Id. at 1390 .

169. See, e.g., Carnation Co. v. Pacific Westbound Conference, 383 U.S. 213, 222 (1966) ("[an] award of damages for past and completed conduct would not interfere with any future action of the Commission"). This would not be true where the Commission has the power to approve the activity retroactively.

In Essential Com. Sys., Inc. v. AT\&T, 610 F.2d 1114 (3d Cir. 1979), a district court injunction directing the carrier to form and file a new tariff was approved by the Fifth Circuit. The appellate court considered that the FCC's concern is with the relationship between the carrier and its customers, not its competitors, and that since the new tariff would have to be filed with the FCC and meet the same requirements as any other tariff, this procedure did not hinder the Commission's fulfillment of its role.

170. A filed tariff, unless and until disapproved, has the force of law. See note 43 supra. To award damages for conduct under it might subject the carrier to inconsistent standards of the very type that would otherwise call for implied iminunity from the antitrust laws. See text accompanying notes 61-67 supra. However, inconsistent standards should be found only where the rate received actual approval and did not merely become effective by acquiescence. See text accompanying notes $62-65$ supra.

171. Where there was no prior approval by the agency, and the carrier claims that the action was induced by regulation, Mid-Texas Com. Sys. v. AT\&T, 615 F.2d 1372 (5th Cir. 1980), suggests that there will be no blanket immunity and no primary jurisdiction referral, but that the jury may take regulation into account in determining the existence of market power. 
relief and damages may be awarded without conflict with agency policymaking powers. If a court enjoins refusal to connect equipment meeting the registration standards, enforcement of FCC policy ${ }^{172}$ is achieved without harm to its standard-setting authority, even in the absence of referral. ${ }^{173}$

\section{CONCLUSION}

Both technology and policy under the Communications Act of 1934 increasingly favor competition in the delivery of telecommumications services. Application of antitrust law to the industry would remforce this policy by providing a treble damages remedy. Present doctrime argues in favor of antitrust law except when there has been actual prior agency approval of the alleged anticoinpetitive behavior. Agency policymaking authority, as well as the integrity of the rate structure, can be preserved by referring questions requiring technical expertise, particularly tariff rate issues, to the agency.

Gail Hillebrand*

172. Carterfone, 13 F.C.C.2d 420 (1968).

173. In Macom Prod. Corp. v. AT\&T, 359 F. Supp. 973 (C.D. Cal. 1973), the district court denied immunity but sent to the FCC the question of whether Bell hardware was harmed by interconnection since it was a technical question then under study by the Commission. The FCC standards and program to register nonharmful equipinent were promulgated in 1975; therefore, referral should no longer be required. See also Chastain v. AT\&T, 351 F. Supp. 1320, 1323 (D.C. Cir. 1972) (another preregistration case) ("This court is unwilling and unable to assume the intital responsibility of evaluating the highly technical questions raised by the parties in this case") (emphasis added). Law.

" B.A. 1977, University of California, San Diego; third-year student, Boalt Hall School of 